\title{
The Implementation of Health Protocols in New Normal Era of Covid-19 in Tourism
}

\author{
Riza Yonita*, Shally Amna \\ Information System department, \\ University of Putra Indonesia YPTK \\ Padang, Indonesia \\ *rizayonitaupi@gmail.com, shallyamna@gmail.com
}

\begin{abstract}
The pandemic of COVID 19 has a massive impact on all economic sectors. Tourism is one of the sectors that is experiencing a setback. The government policy of new normal implementation is meant to provide new hope to this industry. This study examined tourists' behavior and perception toward the implementation of health protocols in the new normal era in a tourism city. The study uses a quantitative approach with an associative clausal method. The population in the study is domestic tourists who visited a tourist city (Bukittinggi) with the total sample is 99 tourists. Data were analyzed by using SPSS 26. The result showed that there were behavioral influences on the implementation of the Covid-19 health protocols in the new normal era with the result of the regression coefficient 0,445 signed for positive, this figure is significant to the value of tcount $>t$ table $(4.549>1.985)$ with a sig value of 0.05 . However, the perception did not have a significant effect on the application of health protocols with the results of tcount $>t$ table $(1.658>$ 1.985 ) with a sig value 0.05 . So, it can be concluded that there is an influence of tourist behavior on the implementation of the Covid-19 health protocol and there is no influence of tourist perception on the implementation of the Covid-19 health protocol.
\end{abstract}

Keywords—health protocols, tourist, behavior, and perception

\section{INTRODUCTION}

Since the emergence of Covid-19 on January 19, 2020, in Wuhan, China, one by one other countries began to contract with the disease. On March 11, 2020, The World Health Organization (WHO) stated a global pandemic status for Corona Virus 2019 (Covid-19) [1].The changing of the situation due to the policy has a very broad impact in almost all sectors, such as transportation, retail, sales and many others, including the tourism sector. The Government Tourism Office said that the estimated loss of tourism sector in DIY was almost IDR 81 billion. The data is obtained based on data from Government Tourism Office which started from March to April $16^{\text {th }}$ [2].Government Tourism Office in Padang, West Sumatera, estimated that the tourism sector workers who have the impact on the Covid-19 pandemic condition were estimated 3,571 people. So that, this is also has an impact on the loss of income from hotel, restaurant and entertainment transactions which reached IDR 174 billion, transactions from the informal sector in tourist objects reached IDR 7 billion, and in cultural sector like traditional dance reached IDR 981 million [3].

To overcome the economic decrease that occurred, the government begun to loosen some policies related to the mobility of its people, even on the other hand, the Covid-19 is still threatening. Therefore, President Jokowi asked the people to improve discipline in implementing health protocols before entering into a new normal lifestyle (New Normal Era) in the midst of the Covid-19 pandemic [4].

The term 'New Normal' means the willingness of many people to follow new rules for a long time because of various consideration that will be very important to do things that really need to be done in the tyranny of urgency [5]. In general, it cannot be denied that these new normal condition include significant changes in the rules and lifestyle of the society over a long period of time for very basic reasons. The new normal has become the choice of many countries because they need to prepare their people to adopt a new way of life which is side by side with the Covid-19. The Indonesian government through the Spokesperson for handling Covid-19, Achmad Yurianto, said that people must maintain their productivity in the midst of Covid-19 pandemic with a new life order called New Normal [6]. According to Yurianto, the new life order and behaviour based on adaptation to cultivate a clean and healthy lifestyle is what is then called as the new normal. The new normal life way is to routinely wash hands with soap, wear a mask when leaving the house, maintain a safe distance and avoid crowds. This is what is expected to become a new habit and a collective awareness for the community. Anyone who manages public places, workplaces, schools, and places of worship must pay attention to this aspect and even take control to the discipline of the society.

New Normal is a new life where people continue to carry out various activities as usual but still apply health protocols established by the government so that the spread of the Covid19 virus can be overcome [7]. In the New Normal or the new life order, the government gives directions for people to wear masks, wash their hands frequently, keep their distance, and so on. According to Roger McNamee, the term 'New Normal' 
means the willingness of many people to follow new rules for a long time because of various consideration that are very important to do things that must be resolved in the tyranny of urgency [5]. As in Carr [8] said that it is undoubtedly there will be many experiences will be diverse and depending on each government response to the health and socioeconomic needs caused by the pandemic. Therefore, it cannot be denied that these normal conditions include significant changes in the rules and lifestyle of society over a long period of time for very basic reasons.

Behaviour is basically the human activity itself, what the organism does, whether it can be observed directly or indirectly. This means that behaviour occurs when something is needed to cause a reaction, namely what is called stimulation. A certain stimulus will produce certain behavioural reactions [9]. It is very important to learn the behaviour or tourists in order to know the development of the tourism business; choice of tourist destinations, evaluation of tourist destinations, and tourist behaviour for future trips [10]. It is also important as information for the tourism industry which has suffered losses during the Covid-19 Pandemic. Tourist behaviour is divided into 5 stages:

- Tourists know the purpose of travelling.

- Tourists have information about tourist attractions.

- Tourists make decisions to come to tourist areas.

- Tourists evaluate tourism activities that have been carried out [11].

The forms of behaviour are as follow:

- Passive Behaviour: A certain behaviour which occurs within the individual and cannot be observed. Example: Thinking and breathing.

- Active behaviour: Behaviour which is open in the form of real actions and can be observed directly [12].

Perception is a feeling of agreeing or disagreeing on the basis of self-encouragement or based on external encouragement. This perception is inherent in sensitive people [9]. In Sangadji [13], Stanton states that perception can be defined as a meaning that we need to relate based on past experiences and stimuli we receive through our five senses. Meanwhile, according to Hawkins and Coney, "Perception is the process by which the stimulus is selected, organized and interpreted."

Person, group of people or tourists can produce perceptions based on two aspects:

- Physical perception: Physical perception is the perception of tourists about the facilities contained in a tourist object.

- Non-physical perception: Non-physical perceptions are tourists' perceptions or assessments of the offered tourist attraction data [14].
The behaviour and perceptions of tourists toward the implementation of this health protocol show and determine the readiness and understanding of the tourists which can be seen from their behaviour and perception towards the policy. It can be concluded that human behaviour is all human activities, both those that are can be directly observed and those that cannot be observed by outsiders [12]. Of course, in this phase, tourist's places must meet all the provisions of the health protocol.

If we solely look at the readiness of the government itself, it is certainly not enough. We must also look at the role of the community in understanding and responding to the health protocol rules, whether these regulations are also obeyed by visitors who come to tourist objects. The existence of Covid-19 certainly changes people's social behaviour, the habits and custom. Many research has been conducted since the beginning of the pandemic of Covid-19. As in Belinda [15], Fera Belinda et al. have done research on how health protocols are applied to ensure safety of visitors so they are not at risk to covid-19. In Pratiwi et al. [16], a research done on how to get the tourists' trust to visit the tourism city with a proper health protocols. However, this research is aimed to see the implementation of Health protocols in new normal era in tourism city Bukittinggi based on the tourists' behaviour and perception.

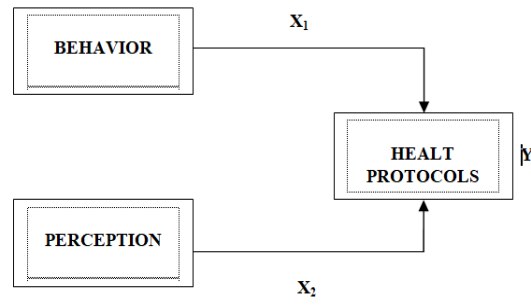

Fig. 1. Theoritical framework

\section{METHODS}

This research is a quantitative-associative study, in which this study aims to determine the influence of behaviour and perceptions as variable $\mathrm{X}$, on the implementation of health protocols in the New Normal Era as variable Y. The object of the research is tourists who visit the tourist city Bukittinggi (Padang, West Sumatera) with unknown numbers of population. As for the consideration of this sample is that the unknown numbers of population used, so that it is impossible for the researcher to take the entire population by considering cost, time and energy. Because of that reason, the researcher only used 100 samples, but one sample is damaged so that the final of total sample used in the study s 99 samples. The technique for analysing data used multiple linear regression analysis using SPSS version 24.0 program.

\section{RESULTS}

Based on the results of data processing using SPSS version 24.0 , it can be seen how much the regression coefficient of 
each independent variable and its effect on the dependent variable can be seen in table 1 :

TABLE I. MULTIPLE LINEAR REGRESSION RESULTS OF RESEARCH VARIABEL

Coefficients $^{\mathrm{a}}$

\begin{tabular}{|c|c|c|c|c|c|}
\hline \multirow[b]{2}{*}{ Model } & \multicolumn{2}{|c|}{$\begin{array}{c}\text { Unstandardized } \\
\text { Coefficients }\end{array}$} & \multirow{2}{*}{$\begin{array}{c}\begin{array}{c}\text { Standardized } \\
\text { Coefficients }\end{array} \\
\text { Beta } \\
\end{array}$} & \multirow[b]{2}{*}{$\mathbf{t}$} & \multirow[b]{2}{*}{ Sig. } \\
\hline & $B$ & Std. Error & & & \\
\hline \begin{tabular}{|l|l|}
1 & (Constant) \\
\end{tabular} & 1.617 & 330 & & 4.902 & .000 \\
\hline Behavior & .445 & .098 & .518 & 4.549 & .000 \\
\hline Preception & .183 & .111 & .188 & 1.654 & .101 \\
\hline
\end{tabular}

Based on table 1, it can be concluded that the constant is 1.671 while the behavioral regression coefficient is 0.445 and the perception is 0.183 . This value can be formulated into the equation:

$$
\mathrm{Y}=1.617+0.445 \mathrm{X}_{1}+0.183 \mathrm{X}_{2}
$$

Information:

\section{Y: Health Protocols}

$\mathrm{X}_{1}$ : Behavior

\section{$\mathrm{X}_{2:}$ Perception}

Based on the equation, it can be explained that:

- Based on table 1, we get a constant value of 1.617 with a positive sign. It means that regardless the behaviour and perceptions, people will implement health protocols when they travel or visit tourist cities.

- The variable regression coefficient (X1) of the behaviour is 0.445 which is positive. Based on this, it can be interpreted that there is an increase in the awareness of the behaviour felt by tourists visiting the tourist city Bukittinggi in implementing health protocols. It can be concluded that the higher the increasing awareness of behaviour in implementing health protocols, the better implementation of health protocols in the New Normal Era.

- The variable regression coefficient (X2) of perception is 0.183 which is positive. This means the higher the perception of tourist on implementing the health protocols, the better the implementation of health protocols in the New Normal Era.

\section{A. Hypothesis Test (t-test)}

This hypothesis was tested using the t test, carried out using the results of table 1, it can be explained as follow: The t-test results obtained from the coefficient table, the value of $t_{\text {count }}$ is 4.549 and $t_{\text {table }}$ with $\mathrm{df}=\mathrm{n}-3$ so that $\mathrm{df}=99-3$ is 1985 . It can be seen that the results of the t-test on the regression coefficient for competence, then the $t_{\text {count }}>t_{\text {table }}(4.549>1.985)$ was obtained with a significant level $(0.00<0.05)$. The two results of the t-statistical test above indicate that the regression coefficient of both is real. Based on this data, behavior has a significant effect on the implementation of health protocols. Whereas for the perception variable, the value of $t_{\text {count }}$ is 0.183 , then it is obtained $t_{\text {count }}>t_{\text {table }}(0.183<1.985)$, so the perception variable on the implementation of health protocols does not have a significant effect. It can be concluded that the perception of tourists on the implementation of the protocol is there or whether or not they still agree to the implementation of the health protocol.

\section{B. Coefficient of Determination}

Based on the results of adjusted $\mathrm{R}$ square, where these results aim to see how much influence variable $X$ has on variable $\mathrm{Y}$, namely the effect of behavior and perceptions on the implementation of the health protocols for tourists visiting the tourist city of Bukittinggi can be seen on table 2 :

\section{TABLE II. MODEL SUMMARY}

\begin{tabular}{|c|c|c|c|c|c|c|}
\hline \multicolumn{7}{|c|}{ Coefficients $^{\mathrm{a}}$} \\
\hline & \multirow[b]{2}{*}{ Model } & \multicolumn{2}{|c|}{$\begin{array}{l}\text { Unstandardized } \\
\text { Coefficients }\end{array}$} & \multirow{2}{*}{\begin{tabular}{|c|}
$\begin{array}{c}\text { Standardized } \\
\text { Coefficients }\end{array}$ \\
Beta \\
\end{tabular}} & \multirow[b]{2}{*}{$\mathbf{t}$} & \multirow[b]{2}{*}{ Sig. } \\
\hline & & $B$ & Std. Error & & & \\
\hline \multirow[t]{3}{*}{1} & (Constant) & 1.617 & .330 & & 4.902 & .000 \\
\hline & Behavior & .445 & .098 & .518 & 4.549 & .000 \\
\hline & Preception & .183 & .111 & .188 & 1.654 & .101 \\
\hline
\end{tabular}

Based on table 2, it can be concluded that the $\mathrm{R}$ square value is 0.449 . This indicates that the contribution of variable $\mathrm{X}$ (Independent), namely behavior and perception of variable $\mathrm{Y}$ (dependent), namely the health protocol in this study was concluded at $44 \%$ while $56 \%$ was determined by other factors which in this study were not examined.

\section{DISCUSSION}

Understand that the existence of Covid-19 is a crisis in a country so that some researchers have emphasized that the management of a tourism crisis must consider welfare destination residents. The rapid growth of mass tourism, with the expansion of tourism related infrastructure, has caused ecological crises in several destination areas. It has been shown that local tourism destination communities are aware of the economic contribution of tourism as well as the associated socio-environmental risk affecting their livelihoods as in Neuburger and Egger [17], results which shows a significant increase in risk perception and travel behaviour due to Covid19. Based on the result of the study stated by Witarsana et al. [14] "Empirical predictions of tourist behaviour after this pandemic ends. There are passion and optimism that tourism will recover faster because the majority of respondents in this study have planned when and where they will immediately after COVID-19 pandemic end with new travel preferences". Moreover, as in Grech et al. [18] research results suggested that government and public health must act to exit lockdown as soon as possible to save the tourism sector. So, it can be concluded that the decision to implement the New Normal is of 
course aimed at improving the economy even though there are pros and cons. From the findings in the field, the results of the first hypothesis (tourist behaviour towards the implementation of health protocols) were obtained. This research was conducted to provide information on how tourists behaviour applies to the implementation of health protocols based on SOP (Standard Operating Procedures) based on the decree of the Minister of Health 2020. The results were obtained based on direct or indirect observations conducted by the researchers, there was a significant $(0.00<0.05)$ behaviour effect on the application of health protocols. It means that there is a change in behaviour, especially tourists in the New Normal Era, on policies made by the government. Based on a survey held on April 2020 in Belot et al. [19]. Study how these factors relate to several behaviour changes, including social-distancing, maskwearing and hand-washing. We focus on individuals living in the United States. The data set follows roughly 6,000 individuals in 6 different countries and includes about 1,000 individuals from four different states in the US, California, Florida, New York, and Texas.

Whereas for the second hypothesis (tourist perceptions on the implementation of health protocols), a positive result is obtained which is the value is higher it means that the better. However in this study, the results are not significant, which is the significant value $(0.183<1.985)$, thus it can be concluded that the research hypothesis is rejected, the perception of tourist has no impact, but it also means the higher the perception the better the effect on the implementation of health protocols in the New Normal Era. This inversely proportional to the results the study [16] stated "indicate that affective risk perception is a significant antecedent of attitude, while cognitive risk perception was found to positively influence subjective norm"

\section{CONCLUSIONS AND SugGESTIONS}

\section{A. Conclusions}

Based on the results of research data processing, the following results are;

- Behavior (X1) has a positive and significant effect on the application of health protocols, where the object of the research is tourists visiting the tourist city of Bukittinggi. The result obtained is the value of $t_{\text {count }}>$ $\mathrm{tt}_{\mathrm{able}}(4.549>1.985)$ with a significant level $(0.00<$ $0.05)$, the two results of the $t$ statistical test above indicate that the regression coefficient of both is real. Based on this data, the behavior has a significant effect on the implementation of health protocols.

- Perception (X2) has a positive but insignificantly to the application of health protocols by a tourist visiting the tourist city of Bukittinggi, where the results show the value of $t_{\text {count }}>t_{\text {table }}(0.183<1.985)$, so the perception variable on the implementation of health protocols does not have a significant effect. It can be concluded that whether there is a perception of tourist about the implementation of the protocol, they still agree with the policy health protocols.

\section{B. Suggestions}

Based on the results of the research in the field and the results of data processing to improve tourist behaviour and perceptions of the implementation of health protocols in the New Normal Era effectively, it can be suggested as follow;

- There is consistency in the role of the government in implementing health protocols to improve tourist behaviour, through education or direct reprimands against tourists who violate the implemented protocols. Many of tourists have perception of the importance of health protocols, but behaviourally sometimes still negligent in its implementation.

- There is a good perception of the importance of implementation, sometimes not accompanied by behaviour. It is better if tourism managers are stricter in monitoring incoming tourists and not providing concessions, because in the field, some tourists who initially carry out protocols such as wearing masks, then remove it indifferently, while the officers just stay silent.

\section{ACKNOWLEDGMENT}

Special acknowledgment are given to the foundation president of University of Putra Indonesia YPTK who has provided the university grants and support for the authors to accomplish the research. Moreover, the authors also thank to the chief of LPPM of UPI YPTK who has guided authors along the way of the research.

\section{REFERENCES}

[1] WHO, "Director-General's opening remarks at the media briefing on COVID19," [Online]. Retrieved from: https://www.who.int/dg/speeches/detail/who-director-general-s-openingremarks-atthe-media-briefing-on-covid-19---11-march-2020 [Accessed on: 04-Nov-2020].

[2] Tim Detikcom, "Efek Virus Corona ke Pariwisata," Detik.com, Apr2020. [Online]. Retrieved from: https://m.detik.com/travel/travelnews/d-4928546/data-efek-virus-corona-ke-wisata-ri-per-23-april-2020 [Accessed on: 04-Nov-2020].

[3] N.L. Pertiwi, "Pekerja Pariwisata di Padang di Rumahkan," Kompas.com, 2020. [Online]. Retrieved from: https://www.google.com/amp/s/amp.kompas.com/travel/read/2020/05/2 5/210900027/sebanyak-3.571-pekerja-pariwisata-di-padang-dirumahkan [Accessed on: 04-Nov-2020].

[4] Nasional Kompas, "Pemerintah Siapkan fase New Normal di Tengah Pandemi," Kompas.com, 2020. [Online]. Retrieved from: https://www.google.com/amp/s/amp.kompas.com/nasional/read/2020/05 127/08141631/saat-pemerintah-persiapkan-fase-new-normal-di-tengahpandemi-covid-19 [Accessed on: 04-Nov-2020].

[5] P. Labarre, "Normal Baru," [Online]. Retrieved from: Fastcompany.com. 30-Apr-2003. 
[6] D.V. Putsanra, "New Normal - Tatanan Baru Beradaptasi dengan Covid$19, " 2020$.

[7] S. Fatimah, "Pembelajaran Di Era New Normal," Lis Scholarsh. Arch., 2012.

[8] A. Carr, "COVID-19, indigenous peoples and tourism: a view from New Zealand," Tour. Geogr., vol. 22, no. 3, pp. 491-502, May 2020.

[9] S. Notoatmodjo, Pendidikan Dan Perilaku Kesehatan. Jakarta: Rineka Cipta, 2007.

[10] A. Kholid, Promosi Kesehatan. Jakarta: Rajawali Press, 2012.

[11] Priyoto, Perubahan dalam perilaku kesehatan konsep dan aplikasi. Yogyakarta: Ghara Ilmu, 2015.

[12] A. Kholid, Promosi Kesehatan dengan Pendekatan Teori Perilaku, Media, dan Aplikasi. Jakarta: Rajawali Press, 2015.

[13] E.M. Sangadji, Metodologi Penelitian - Pendekatan Praktis dalam Penelitian. Yogyakarta: Andi Offset, 2010

[14] I.K. Witarsana, L.G.L.K. Dewi, and N.G.A.S. Dewi, "Motivasi dan presepsi wisatawan mancanegara Berwisata Alam Trekking Mountain di
Taman Wisata Alam Gunung Batur Bukit Payang," Jurnal IPTA (Industri Perjalanan Wisata), vol. 5, no. 1, pp. 13-19, 2017.

[15] F. Belinda, "Culture Based Tourism Study in New Normal Era in Bandung District," Int. Rev. Humanit. Stud., vol. 5, no. 2, pp. 524-534, 2020.

[16] R. Pratiwi, R. Rama, and N. Sulistiyanti, "Building the Trust for The Tourism Destination Resiliency in New Normal Society (The Role Of Wellness Tourism System)," J. IKRA-ITH Hum., vol. 5, no. 1, pp. 1-9, 2020 .

[17] L. Neuburger and R. Egger, "Travel risk perception and travel behaviour during the COVID-19 pandemic 2020: a case study of the DACH region," Curr. Issues Tour., pp. 1-14, 2020.

[18] V. Grech, P. Grech, and S. Fabri, "A risk balancing act - Tourism competition using health leverage in the COVID-19 era," Int. J. Risk Saf. Med., vol. 31, no. 3, pp. 121-130, 2020.

[19] M. Belot, S. Choi, J.C. Jamison, N.W. Papageorge, E. Tripodi, and E. Van den Broek-Altenburg, "Six-country survey on COVID-19," 2020. [Online]. Retrieved from: Discussion Paper 13230. IZA. [Accessed on: 04-Nov-2020]. 